hormone this may help to explain the association of cigarette smoking with various menstrual disorders, including an early menopause. ${ }^{2}$ Thus smoking may have hormonal effects due, at least partly, to an increased release of dopamine.

1 Baron JA. Cigarette smoking and Parkinson's Disease. Neurology ( $N Y$ ) (in press).

2 Andersson K, Fuxe K, Eneroth P, Mascagni F, Agnati LF. Effects of acute intermittent exposure to cigarette smoke on catecholamine levels and turnover in various types of hypothalamic DA and NA nerve terminal systems as well as on the secretion of adenohypophyseal hormones and corticosterone. Acta Physiol Scand 1985;124:277-85.

$3 \mathrm{Kwa}$ HG, Wang DY. An abnormal luteal-phase evening peak of plasma prolactin in women with a family history of breast cancer. Int $\mathcal{C}$ Cancer 1974;20:12-4.

4 Seyler LE Jr, Pomerleau OF, Fertig JB, Hunt D, Parker K. Pituitary hormone response to cigarette smoking. Pharmacol Biochem Behav' 1986;24:159-62.

5 Andersson K, Eneroth P, Agnati LF. Nicotine-induced increases of noradrenaline turnover in discrete noradrenaline nerve terminal systems of the hypothalamus and the median eminence of the rat and their relationship to changes in the secretion of adenohypophyseal hormones. Acta Physiol Scand 1981;113:227-31.

(Accepted 3 fune 1986)

Department of Medicine, Dartmouth Medical School, Hanover, New Hampshire 03756, United States of America

JOHN A BARON, MD, MS, associate professor of medicine

Department of Clinical Endocrinology, Imperial Cancer Research Fund, London

R D BULBROOK, PHD, head of clinical endocrinology

D Y WANG, PHD, staff scientist

Netherlands Cancer Institute, Amsterdam

H G KWA, PHD, staff scientist

Correspondence to: Dr Baron.

\section{Leucocytoclastic vasculitis and pneumonitis induced by metformin}

We present what is to the best of our knowledge the first reported case of vasculitis and pneumonitis induced by metformin.

\section{Case report}

A 59 year old woman was admitted to the department of dermatology because of a purpuric eruption on her legs, thighs, buttocks, forearms, and lower abdomen that had started two weeks previously. During this period the patient had also experienced arthralgia of the ankles without fever. For the past five years she had been treated for non-insulin-dependent diabetes mellitus with glibenclamide, $10 \mathrm{mg} /$ day. Four months before admission she had also been given metformin, $2 \cdot 55 \mathrm{~g} /$ day

On admission the patient was in good general condition; her blood pressure was $130 / 80 \mathrm{~mm} \mathrm{Hg}$, she had a pulse rate of 82 beats $/ \mathrm{min}$, and a temperature of $36.5^{\circ} \mathrm{C}$. Slightly indurated purpuric papules were seen on the lower abdomen, thighs, forearms, buttocks, and legs. Some of those on the legs had delicate haemorrhagic vesicles in the centre. Other findings included an apical systolic murmur with normal pulses and a mild, painful swelling of the ankles. Chest radiography showed bilateral basilar pulmonary infiltrates. Specimens taken by punch biopsy of a purpuric papule from the thigh showed an intense perivascular polymorphonuclear infiltrate, fibrinoid deposits in the small dermal vessels, and fragmented neutrophils (nuclear "dust") consistent with leucocytoclastic vasculitis. ${ }^{1}$ Direct immunofluorescence did not show evidence of immune deposits of IgM, IgG, or C3. Glibenclamide and metformin were discontinued and replaced with injections of insulin. Prednisone $0.5 \mathrm{mg} / \mathrm{kg} / \mathrm{day}$ was given orally and rapidly tapered according to her clinical condition. Repeated chest radiography 10 days after beginning treatment showed a clear diminution in the size of the lung infiltrates. The patient was discharged after four weeks and prescribed $20 \mathrm{mg} /$ day of prednisone and daily injections of insulin.

The rapid improvement of the eruption after discontinuing metformin and glibenclamide suggested the possibility of the patient's hypersensitivity to these drugs. Other causes for leucocytoclastic vasculitis were ruled out as the laboratory results-antinuclear factor, latex, Rose-Waaler, C3, hepatitis B surface antigen, protein electrophoresis, and cryoglobulin-were negative or within normal limits.

The patient was admitted to the department of medicine two weeks after discontinuing prednisone. Metformin was reintroduced, and two days later an identical eruption was observed. This eruption disappeared progressively after metformin was stopped.

\section{Comment}

Vasculitis is one of the most common and severe forms of drug eruption. ${ }^{2}$ The similarity between the experimental Arthus phenomenon and the histological findings, in which fibrinoid and polymorphonuclear infiltrates are predominant features, suggests that immune complexes play a part in the pathogenesis of leucocytoclastic vasculitis. ${ }^{2}$ The failure to find immunoglobulin in the lesion may have been due to its rapid clearance-that is, within eight to 18 hours-as in the Arthus phenomenon.

1 Ackerman $\mathrm{AB}$. Vasculitis. In: Ackerman $\mathrm{AB}$, ed. Histologic diagnosis of inflammatory skin diseases. Philadelphia: Lea and Febiger Inc, 1978:337-43.

2 Ryan TJ, Wilkinson DS. Cutaneous vasculitis. In: Rook AJ, Wilkinson DS, Ebling FJG, eds. Textbook of dermatology. Oxford and Edinburgh: Blackwell Inc, 1978:1001-12.

(Accepted 13 fune 1986)

Departments of Dermatology and Medicine, Hadassah University Hospital, 1L-91120 Jerusalem, Israel

L KLAPHOLZ, MD, registrar in dermatology

E LEITERSDORF, MD, lecturer in medicine

L WEINRAUCH, MD, acting head, department of dermatology

Correspondence to: Dr Weinrauch.

\section{Chylopericardium, chylothorax, and hypobetalipoproteinaemia}

We describe a patient with chylous effusions in the pericardial and pleural spaces who also had familial hypobetalipoproteinaemia. A family study was performed.

\section{Case report}

A 21 year old woman had developed a symptomatic left chylothorax at the age of 9 (1973). A chest $x$ ray film after aspiration showed that the heart was enlarged and pear shaped and an electrocardiogram showed low voltage complexes. Further cardiac investigations were recommended but not performed. After reaccumulation of the pleural effusion decortication of the left lung was performed. Preoperative lymphangiography and operative blue dye injections failed to disclose the site of leakage. There were no comments about the heart.

Over the next four years the patient was asymptomatic but chest radiographs showed further, progressive cardiac enlargement. She was admitted for investigation. Pericardial aspiration produced $270 \mathrm{ml}$ chyle. After aspiration the heart size was normal. Serum lipid analysis was not performed.

Over the next three years the pericardial effusion reaccumulated. During three weeks in 1980 she developed anorexia, weight loss, lethargy, dyspnoea, and ankle swelling. On admission she was thin and pale and had the physical signs of a pericardial effusion. This was confirmed by echocardiography. Examination showed nothing else of note. Her haemoglobin concentration was $107 \mathrm{~g} / \mathrm{l}$ with iron deficient indices and frequent acanthocytes in the blood film. Serum lipoprotein analysis (see table) showed hypobetalipoproteinaemia. Results of the chromium chloride test for protein losing enteropathy, faecal fat estimation, and findings on bipedal lymphangiography were normal.

Plasma low density lipoprotein cholesterol concentrations of members of reported family

\begin{tabular}{lcl}
\hline & $\begin{array}{c}\text { Low density lipoprotein } \\
\text { cholesterol concentration } \\
(\mathrm{mmol} / \mathrm{l})\end{array}$ & \multicolumn{1}{c}{ Comment } \\
\hline Relationship to propositus & & \\
\hline Propositus: & $1 \cdot 38$ & Hypobetalipoproteinaemia \\
Preoperative & $2 \cdot 00$ & Hypobetalipoproteinaemia \\
Postoperative & $1 \cdot 49$ & Hypobetalipoproteinaemia \\
Sister 1 & $0 \cdot 96$ & Hypobetalipoproteinaemia \\
Sister 2 & $1 \cdot 62$ & Hypobetalipoproteinaemia \\
Mother & $1 \cdot 48$ & Hypobetalipoproteinaemia \\
Father & $2 \cdot 06$ & Hypobetalipoproteinaemia \\
Paternal aunt & $2 \cdot 78$ & Normal \\
Paternal grandmother & - & Dead \\
Paternal grandfather & $3 \cdot 65$ & Normal \\
Maternal uncle & $2 \cdot 14$ & Borderline \\
Maternal aunt & $3 \cdot 87$ & Normal \\
Maternal grandmother & $3 \cdot 11$ & Normal \\
Maternal grandfather & &
\end{tabular}

Conversion: SI to traditional units-Cholesterol: $1 \mathrm{mmol} / \mathrm{l} \approx 38.6 \mathrm{mg} / 100 \mathrm{ml}$

Laparotomy and exploration of the pericardium through an abdominal approach disclosed an area of lymphangiectasia $1.5 \mathrm{~cm}$ diameter in the small bowel mesentery. The pericardium was opened atraumatically and found to contain 1 litre of heavily bloodstained chyle (haemoglobin concentration $47 \mathrm{~g} / \mathrm{l}$ ). The pericardium was only slightly thickened and the heart normal. A pericardial window was formed. 